\title{
The Political Influence of Foreign Firms in Developing
}

\author{
Countries*
}

\author{
Rodolphe Desbordes ${ }^{\dagger}$ and Julien Vauday \\ CES-University of Paris I Panthéon-Sorbonne-CNRS-IRES
}

October 2, 2006

\begin{abstract}
Foreign firms are likely to attempt to shape host government policies in their favour, since the profitability of MNE foreign affiliates largely depends on the business environment in which they operate. Based on data from the World Business Environment Survey, this paper investigates the political influence of foreign firms in 48 developing countries. It is found that foreign firms derive substantial fiscal and regulatory advantages from their political influence and from their ability to negotiate superior entry conditions.
\end{abstract}

\footnotetext{
* The authors would like to thank Céline Azémar and one anonymous referee for useful comments and suggestions. The financial support of the Belgian French speaking community (ARC 03/08-302) is gratefully acknowledged.

${ }^{\dagger}$ Corresponding author. Address: Maison des sciences économiques, 106-112 Bld de l'Hôpital, 75647 Paris Cédex 13, France. Tel and Fax numbers: (0033) (1) 144078 242/267. E-mail: rodolphe.desbordes@univparis1.fr.

${ }^{\ddagger}$ Address: Maison des sciences économiques, 106-112 Bld de l’Hôpital, 75647 Paris Cédex 13, France. Tel and Fax numbers: (0033) (1) 144078 242/267. E-mail: julien.vauday@univ-paris1.fr.
} 


\section{Introduction}

“[...] Dunning's eclectic paradigm can be readily expanded to include political elements in its consideration of firm-specific, internalization and location advantages. However, this expansion requires accepting that various non-market forces (e.g. the government) may be endogenized instead of simply conceptualizing them as unalterable 'givens' that are 'out there'" (Boddewyn, 1988, p.357).

Recent works, on multinational enterprises (MNE) location choice in developing countries, have acknowledged the importance of public governance as a key determinant of foreign direct investment (FDI), since the profitability of MNE foreign affiliates largely depends on the business environment in which they operate (see for instance, Globerman and Shapiro (2003)). Although these studies tend to see host government policies as exogenous to MNE strategies, it is likely that foreign firms try to shape the business environment in their favour (Boddewyn, 1988; Hillman and Hitt, 1999).

Such corporate political strategy has been mostly investigated by the endogenous protection literature, which has progressively shifted its emphasis from a passive role of MNE in the determination of the level of trade protection to an active political participation in the decisionmaking. In early works, FDI influences the level of trade protection by its mere presence: motivated by a protectionist threat, foreign firms undertake 'quid pro quo' direct investments, which alleviate protectionist pressures by reducing the supply and demand for protection (Bhagwati, 1987; Bhagwati et al., 1992; Grossman and Helpman, 1996; Blonigen and Figlio, 1998). ${ }^{1}$ While in 'quid pro quo' models, foreign firms are passive political actors, several papers have started considering the possibility that foreign investors directly influence the level of trade barriers through lobbying. Mostly based on the Grossman and Helpman (1994) framework, they show that the policy-contingent campaign contributions of foreign firms to the government can lead either to trade liberalisation (Hillman and Ursprung, 1993; Olarreaga, 1999; Gawande et al., 2004) or stronger trade protection (Grether et al., 2001). ${ }^{2}$

These trade policy outcomes depend on the extent of political influence enjoyed by a foreign

\footnotetext{
${ }^{1}$ They can buy goodwill from the host country government or coopt the domestic firms, workers and communities who benefit from their presence.

${ }^{2}$ Other works have analysed the impact of foreign lobbying on the choice between alternative trade policy instruments; see for instance Hillman and Ursprung (1988), Ellingsen and Wärneryd (1999) or Konishi et al. (1999).
} 
firm, compared to a domestic firm. Most of the previously cited papers assume that foreign and domestic producers share the same level of political influence and conclude that foreign lobbying generally leads to lower tariffs. Estimates of Gawande et al. (2004) indicate that such weighting is about right in the U.S. government case. However, in Grether et al. (2001), the higher sensitivity of a government to demands from foreign firms than from domestic producers lead, under certain conditions, to an increase in trade protection; their econometric analysis indirectly supports this analysis since they find that FDI-intensive sectors in Mexico tended to be over-protected during the 1986-1990 period. In comparison to developed countries, developing countries may therefore give more voice to foreign firms for various reasons. It is also possible that foreign firms hold less political influence than an equivalent domestic firm in most developing countries, as postulated by traditional models of government policies towards affiliates of foreign MNE (Caves, 1996). In this case, trade liberalisation is likely to be weaker. Hence, depending on the political influence of a foreign firm, relative to the one hold by a domestic counterpart, endogenous policy models may not yield the same conclusions. ${ }^{3}$ The fact that foreign firms can decisively shape government policies can have profound consequences for the host country. For instance, successful foreign lobbying for a reduction of trade barriers should improve domestic consumer surplus and possibly increase aggregate welfare (Olarreaga, 1999). On the other hand, Cole et al. (2006) put forward that the lobbying of MNE can result in a relaxation of pollution regulations and the subsequent creation of pollution havens if the government gives a lot of weight to campaign contributions in its objective function.

Hellman et al. (2002) is the only study to have examined the political behaviour of foreign firms in developing countries. In line with Grossman and Helpman (1994) model, they show that foreign firms, by bribing more frequently public officials than their domestic counterparts, enjoy substantial private gains from this strategic behaviour, at the expense of the rest of the economy. However, their results do not give any clue on whether domestic and foreign producers diverge in terms of bribing efficiency. ${ }^{4}$ Furthermore, the authors ignore the possibility that foreign firms

\footnotetext{
${ }^{3}$ In addition, the lobbying motives of foreign firms depend on whether they are located in the host country, on their trade orientation and on their mode of entry (Olarreaga, 1999; Grether et al., 2001).

${ }^{4}$ Firms were asked: "How often do firms like yours need to make extra unofficial payments to public officials to influence the content of new laws, decrees or regulations?" The responses ranged across always; usually; frequently; sometimes; seldom and never. Thus, more frequent bribes result in more favourable policies. However, it is unclear whether the benefits derived from identical contributions would be the same if the firm was either foreign or domestic.
} 
may influence the government through legal means, i.e. through political influence. ${ }^{5}$ With the entry into force of the OECD Anti-bribery Convention, foreign firms from developed countries are increasingly likely to resort to legal lobbying activities. Finally, their sample only includes firms located in East Europe and Central Asia, in which the new institutions are extremely malleable and not fully implemented.

This paper is then the first study to empirically investigate whether foreign and domestic firms possess diverging levels of political influence and whether political influence leads to a better business climate than the one to which non-influential firms are subject. This enquiry is made possible by the availability of the World Business Environment Survey data. It is a survey of over 10000 domestic and foreign firms in 80 countries, conducted in 1999-2000, which examines a wide range of interactions between firms and the state. ${ }^{6}$ Among other questions, firms were asked to rate their influence on the content of a new regulation which may substantially affect the conduct of their business. The answers provide, after some adjustments relative to the elimination of any illegal influence achieved through bribery of public officials, an unique measure of a firm's political influence, i.e. influence achieved through legal means. The distinction between political and illegal influence is crucial. The level of political influence enjoyed by a firm can be interpreted as the extent to which the intrinsic characteristics of a firm allow it to wield political power over public officials, with the goal of having an impact on the formation of the rules of the game. On the contrary, firms which influence the government through outright bribery do not exert a direct power over politicians; their preferential treatment only results from their illegal activities (Hellman et al., 2003). This paper puts emphasis on the political influence of firms for three reasons. First, the WBES does not provide any detailed data on how firms influence public officials through illegal means. Second, although the endogenous protection literature fully acknowledges that political influence can lead to the "privatisation of public policy" (Kaufmann et al., 2004), most attention has been devoted to illegal forms of influence. Finally, the fact that the degree of political influence enjoyed by a firm depends on its intrinsic characteristics implies that any diverging political influence between a foreign and a domestic firm is likely to be caused by structural differences.

\footnotetext{
${ }^{5}$ In Hellman et al. (2003), they investigate the determinants of political influence in East Europe and Central Asia countries but they do not take into account the nationality of firms.

${ }^{6}$ The dataset and the questionnaire are available at http://info.worldbank.org/governance/wbes/ index.html.
} 
This paper proposes a conceptual framework in which the political influence of a foreign firm, compared to the one held by its domestic counterpart, depends on three factors ceteris paribus: the host country belief that its presence will contribute to economic growth, the extent of its political liability of foreignness and its multinationality. On the one hand, it can be argued that a foreign firm will exert a stronger political influence on government policies than a domestic firm because it may be seen as an essential contributor to domestic growth, thanks to its advanced technology. On the other hand, governments may discriminate foreign firms against domestic firms because the former suffers from a political liability of foreignness. Finally, international operations may give MNE, be they foreign or domestic, two advantages, in terms of relocation threat credibility and international experience. The strength of a foreign firm's political influence depends in fine on the relative weight of each of these determinants.

In a first stage, these three hypotheses are tested econometrically, by using a sample of 4085 firms in 48 developing countries. Estimations indicate that foreign and domestic firms generally share the same degree of political influence, though hybrid MNE, i.e dual nationality MNE, are more influential than all other firms. These outcomes suggest that the bargaining power of foreign firms is generally high enough to outweigh any political lability of foreignness and that the stronger political influence of hybrid MNE results from their extensive multinationality rather from their expected contribution to host country growth. In a second stage, it is investigated whether foreign and influential firms are privileged by the government. It is found that they both indeed enjoy a better business climate, in benefiting from lower fiscal and regulatory constraints. The advantages enjoyed by foreign firms over domestic firms are then a consequence of two effects. First, thanks to their expected potential contribution to growth, foreign MNE hold enough bargaining power to negotiate favourable entry conditions with a host country, in terms of regulatory concessions and lower taxes. Second, hybrid MNE derive from their extensive international operations sufficient political power to influence any new government regulation which may affect their business operations. This last effect is much stronger in East Europe and Central Asia, where institutions are relatively malleable and civil society weak. Generally, nationality and political influence explain respectively one-third and two-thirds of the difference in probabilities that a fully influential foreign firm and a non-influential domestic firm will enjoy a low fiscal and regulatory burden. Thus, foreign firms which successfully influence the host country government are likely to benefit from a significant competitiveness advantage, 
compared to their domestic competitors.

The paper is constructed as follows. Section II introduces the political influence variable. Section III proposes a conceptual framework which explains the determinants of a foreign firm's political influence, compared to a domestic firm. Section IV provides an econometric test of the comparative political influence of foreign and domestic firms. Section V investigates whether influential and foreign firms enjoy fiscal and regulatory advantages denied to other firms. Section VI concludes.

\section{The measure of political influence}

To measure political influence, the answer to the following question, taken from the World Bank Environment survey (WBES) carried in 1999-2000, is used: "When a new law, rule regulation or decree is being discussed that could have a substantial impact on your business, how much influence does your firm typically have at the national level of government to try to influence the content of that law, rule regulation or decree?". The answers were (1) never influential (2) seldom influential (3) influential (4) frequently influential (5) very influential and the question concerned separately the estimated influence on the executive, the legislature, the ministry and the regulatory agency. The overall influence of a firm over a government, on a 1-5 scale, corresponds to the average of the four answers, rounded to the nearest unit. Data are available for 4085 firms in 48 countries, located in East Europe and Central Asia (23 countries), Latin America and the Caribbean (20 countries) and South and East Asia (5 countries).

The measure of influence obtained can be interpreted as reflecting the legal and illegal political behaviours of firms. Although no reference was made to illegal payments when firms were asked about their influence, it does not necessarily imply that firms do not achieve influence through corruption of public officials. Since this paper focuses on the political influence of firms, the measure of influence should be purged of any illegal influence achieved through bribery. Answers to the following question included in the WBES provides some information on the bribing behaviour of firms "It is common for firms in my line of business to have to pay some irregular 'additional payments' to get things done. This is true (1) always (2) mostly (3) frequently (4) sometimes (5) seldom (6) never". Consistent with this last answer, $70 \%$ of firms which report never or seldom paying bribes also indicate that on average $0 \%$ of their 
sales are earmarked for unofficial payments to public officials. ${ }^{7}$ Although it is impossible to ascertain whether these bribes serve the purpose of illegally influencing the contents of new government rules, which may lead to an underestimation of the genuine political influence of certain firms, not taking into account this possibility would defeat the purpose of this paper. Hence, whichever the value of the influence variable, a firm is considered to exert some political influence over a government only if it reports never or seldom paying bribes. ${ }^{8}$

As Table 1 shows, distinguishing between overall influence and political influence yields strikingly different results in terms of the percentage of firms, in each country sample, which consider themselves influential. For instance, in Indonesia, little political influence can exist without corruption of public officials whereas the opposite is true in Chile. Correlations between these two ratios and the Corporate Legal Corruption Index (CLCI) developed by Kaufmann $(2004)^{9}$ clearly indicate that a better picture of politically influential firms is obtained by not considering firms which may achieve their influence through corruption. Furthermore, after correcting for the potentially illegal political behaviour of firms, it appears that about the same percentage of firms across developing regions report that they exert political influence over government policies. ${ }^{10}$

At the aggregate country level, the achievement of influence through political means certainly depends on the quality of its public governance. Table 2 indicates the correlation coefficients between the share of politically influential firms in the sample and various indicators of public governance quality computed by Kaufmann et al. (2004) for the year 1998. They have evaluated six dimensions of public governance, on the basis of polls of experts or surveys of businessmen/citizens: voice and accountability (VOICE), political stability (POLSTAB), government effectiveness (GVTEFF), regulatory quality (REGQ), rule of law (RLAW) and control of corruption (CCORR). The first two clusters attempt to capture the process by which those

\footnotetext{
${ }^{7}$ Firms were asked "On average, what percent of sales do firms like yours typically pay per annum in unofficial payments to public officials?". The answers were 0\%, less than 1\%, 1-1.99\%, 2-9.99\%, 10-12\%, 13-25\%, over $25 \%$.

${ }^{8}$ Firms which report seldom paying bribes are included since in East Europe and Central Asia, it seems that business cannot be conducted without paying unofficial payments to public officials: for most countries of this region, $100 \%$ of sampled firms indicate paying bribes.

${ }^{9}$ This index measures legal dimensions of undue political influence, based on the percentage of firms in a country surveyed in the 2004 Executive Opinion Survey of the World Economic Forum which give satisfactory ratings to the questions on influencing legal political funding and undue political influence.

${ }^{10} \mathrm{~A}$ comparison of means test indicates that differences between means are not significant at the $10 \%$ level.
} 


\begin{tabular}{|c|c|c|c|c|c|}
\hline Country & $\begin{array}{l}\text { Influential } \\
\text { firms (\%) }\end{array}$ & $\begin{array}{l}\text { Politically } \\
\text { influential } \\
\text { firms (\%) }\end{array}$ & Country & $\begin{array}{l}\text { Influential } \\
\text { firms (\%) }\end{array}$ & $\begin{array}{l}\text { Politically } \\
\text { influential } \\
\text { firms (\%) }\end{array}$ \\
\hline Albania & 40 & 13 & Kyrgizstan & 25 & 3 \\
\hline Argentina & 41 & 19 & Lithuania & 33 & 16 \\
\hline Armenia & 30 & 9 & Malaysia & 75 & 28 \\
\hline Azerbaijan & 16 & 8 & Mexico & 41 & 11 \\
\hline Belarus & 30 & 18 & Moldova & 60 & 22 \\
\hline Belize & 74 & 35 & Nicaragua & 38 & 10 \\
\hline Bolivia & 55 & 11 & Pakistan & 71 & 8 \\
\hline Bosnia & 58 & 35 & Panama & 71 & 39 \\
\hline Brazil & 42 & 20 & Peru & 47 & 24 \\
\hline Bulgaria & 44 & 26 & Philippines & 87 & 24 \\
\hline Chile & 54 & 43 & Poland & 26 & 13 \\
\hline Colombia & 61 & 37 & Romania & 31 & 6 \\
\hline Costa Rica & 62 & 37 & Russia & 27 & 12 \\
\hline Croatia & 74 & 42 & Singapore & 65 & 61 \\
\hline Czech Republic & 33 & 12 & Slovakia & 38 & 17 \\
\hline Dominican Republic & 59 & 25 & Slovenia & 44 & 35 \\
\hline Ecuador & 54 & 14 & Trinidad\&Tobago & 71 & 55 \\
\hline El Salvador & 35 & 19 & Turkey & 46 & 7 \\
\hline Estonia & 60 & 28 & Ukraine & 49 & 21 \\
\hline Georgia & 51 & 29 & Uruguay & 59 & 38 \\
\hline Guatemala & 40 & 21 & Uzbekistan & 40 & 20 \\
\hline Haiti & 40 & 5 & Venezuela & 46 & 14 \\
\hline Honduras & 33 & 16 & & & \\
\hline Hungary & 18 & 5 & Latin America & 51 & 25 \\
\hline Indonesia & 73 & 5 & South and East Asia & 74 & 25 \\
\hline \multirow[t]{2}{*}{ Kazakhstan } & 20 & 9 & E. Europe and C. Asia & 39 & 18 \\
\hline & & & Corr. CLCI & 0.24 & $0.41^{* * *}$ \\
\hline
\end{tabular}

Notes: $\%$ of sample. ${ }^{* * *}$ indicates that the correlation coefficient is significant at the $1 \%$ level. CLCI: Kaufmann (2004)'s Corporate Legal Corruption Index (CLCI); a higher value implies a higher ethical standard rating given by the country's enterprise sector.

Table 1: Share of influential and politically influential firms in the sample, by country 
in authority are selected and replaced, the next two clusters are related to the ability of the government to formulate and implement sound policies and the last two clusters assess the respect of citizens and the state for the institutions which govern their interactions. ${ }^{11}$ Table 2 clearly shows that there are more politically influential firms in countries which are well governed. The high correlations with the government efficiency, rule of law and control of corruption indicators suggest two reasons for explaining this relationship. First, in badly-governed countries, firms are unlikely to attempt influencing legally the shaping of new laws or rules when their application depends in fine on public officials goodwill. Second, corruption is not without risk for the payer and the bribe recipient, since there is always the possibility that they could get caught. This risk probably increases with the quality of public governance and therefore in well-governed countries, most of firms and public officials may be too afraid of the legal consequences to engage themselves in illicit activities. Hence, the single alternative remaining for firms willing to influence new rules in their favour is to use legal means.

\begin{tabular}{|l|cccccc|}
\hline \multicolumn{1}{|c|}{ Governance Indicators } & VOICE & POLSTAB & GVTEFF & REGQ & RLAW & CCORR \\
\hline $\begin{array}{l}\text { Coefficient of correlation } \\
\text { with share of politically } \\
\text { influential firms }\end{array}$ & $0.30^{* *}$ & $0.39^{* * *}$ & $0.54^{* * *}$ & $0.34^{* *}$ & $0.55^{* * *}$ & $0.58^{* * *}$ \\
\hline
\end{tabular}

Notes: '**, ‘***) respectively indicate that the correlation coefficient is significant at the 5 and $1 \%$ level.

Table 2: Correlations between the share of politically influential firms in each country sample and various public governance indicators

All in all, it has been established that the variable constructed is a good proxy for the political influence of firms. In the next section, it will be investigated the determinants of a foreign firm's political influence, compared to its domestic counterpart.

\footnotetext{
${ }^{11}$ For a comprehensive discussion of these indicators, see Kaufmann et al. (2004).
} 


\section{The determinants of a foreign firm's political influ-}

\section{ence}

The political influence of a foreign firm, compared to its domestic counterpart, depends on three factors: the host country belief that its presence will contribute to economic growth, the extent of its liability of foreignness and its multinationality.

\section{Foreign firms and economic growth}

Foreign firms can foster economic growth through their contribution to labour and capital stocks and their transfer of advanced technology. ${ }^{12}$ This technology transfer arises from the fact that a necessary condition for a firm to invest in a foreign country is an ownership advantage over at least one internationally transferable knowledge asset, known as a firm-specific advantage (FSA), which allows it to overcome the difficulties of competing with local firms (Hymer, 1960; Carr et al., 2001). ${ }^{13}$ By definition, the technology used by foreign $\mathrm{MNE}^{14}$ is not available to domestic firms, but foreign firms may contribute to its diffusion in the host country if their activities generate productivity spillovers, through demonstration effects, labour turnover, vertical linkages or increased competition. ${ }^{15}$ Developing countries, which have increasingly integrated the contribution of MNE in their development strategy (Kobrin, 2005), are therefore eager to attract the foreign firms which can provide the domestic economy with the highest growth benefits. The bargaining power of a MNE, in the negotiation of its entry conditions with a government, is therefore likely to depend on its potential contribution to host country economic growth. Cross-sectional (Fagre and Wells, 1982; Lecraw, 1984) and longitudinal studies (Vachani, 1995) validate this hypothesis. They show that the bargaining power of a foreign MNE, proxied by its ability to obtain its desired equity share in its foreign affiliate, depends on its technology level.

The bargaining power of a foreign MNE should not be limited to the negotiation of its entry

\footnotetext{
${ }^{12}$ Numerous surveys have comprehensively examined the impact of FDI on host country productivity and economic growth. See Blomström and Kokko (1998); Saggi (2000); Lipsey (2002); Görg and Greenaway (2002).

${ }^{13}$ The notion of FSA/technology should be interpreted broadly, since it encompasses production processes, management techniques, marketing methods or means of finance.

${ }^{14}$ As it will be seen later on, the distinction between foreign MNE, i.e. a foreign firm, and domestic MNE matters.

${ }^{15}$ For Saggi (2000) the competition effect should not be included in a strict definition of spillovers because it is not a pure externality: innovation in a domestic industry caused by increased competition from foreign MNE is a "benefit enjoyed by the host country that works its way through the price mechanism" (Ibid., p.18). However, in most studies, pure and pecuniary externalities are not distinguished.
} 
conditions in the local market. In opposition to Vernon (1971)'s obsolescing bargain model, in which a MNE loses its power once it has sunk its assets in a developing country, Dunning (1998) and Luo (2001) emphasise that relations between a foreign MNE and a host country government have progressively become less confrontational and more cooperative because both actors recognise that their interests are compatible and that their resources are complementary. If the objective of the government is to ensure that the foreign MNE will carry on contributing to the economy in the long-run, through reinvestment or technology upgrading, it is likely that it will adopt a cooperative stance, consulting or taking into account a foreign firm's opinion about any new regulation affecting its business conditions (Luo, 2001). Even in the long-run, foreign MNE may therefore hold some political influence if they are seen as long-term contributors to economic growth.

Hence, a foreign firm may possess a stronger political influence on government policies than a domestic firm because its advanced technology could be highly valued and desired by a government wishing to promote economic growth. However, as it will be seen in the next section, traditional models of government policies towards affiliates of foreign MNE assume that a government will privilege domestic firms over foreign firms, for electoral or nationalistic reasons.

\section{The political liability of foreignness}

Among the costs of going abroad faced by a firm, can be found those engendered by a lack of societal legitimacy and by economic nationalism (Zaheer, 1995; Kostova and Zaheer, 1999). Thus conventional frameworks, describing host country policies towards affiliates of foreign MNE, suggest that foreign firms will be discriminated against domestic firms. For instance, in the national preference model exposed in Caves (1996), a democratic government, trying to get reelected, may decide to redistribute income at the expense of foreigners. Since foreigners do not vote in national elections and domestic producers do not receive any income from the activities of foreign producers, this will cause no harm to the government, in terms of negative votes. ${ }^{16}$ Foreign enterprises may also be imposed "performance requirements," which frequently engender a deterioration of the operating conditions of foreign enterprises (Moran, 1998; UNCTAD, 2003), in order to allegedly increase the development benefits of foreign presence. Voters

\footnotetext{
${ }^{16}$ Although this model acknowledges that foreign firms can influence the government through other channels, such as campaign contributions, Caves (1996) remarks that "in general the political influence of foreigners is sensibly regarded as discounted from that of equivalent domestic business units" (p.250).
} 
may also favour measures restricting or regulating foreign operations because they experience some utility from the discrimination of foreigners, due to nationalistic or xenophobic feelings. In every case, foreign firms are discriminated against domestic firms. ${ }^{17}$ Public questioning of the legitimacy of foreign firms may even encourage them to adopt deliberately a low profile, leading to few political interventions (Mitchell, 1995) or to the targeting of policy-enforcers rather than elected public officials (policy-makers).

A high political liability of foreignness may therefore leave foreign firms at a disadvantage against domestic firms in terms of political influence, especially when facing politicians. ${ }^{18}$

\section{The international operations of foreign and domestic firms}

A MNE, by definition, operates in several countries. Its gradual expansion overseas engender the formation of new firm-specific advantages, known as "economies of common governance" (Dunning, 1993, 2001). In other words, they do not exist before the multinationalisation of the firm but result from its multinationality per se. ${ }^{19}$ Purely domestic firms, i.e. not foreignowned and without foreign operations, do not benefit from these advantages of multinationality which allow MNE to arbitrage institutional restrictions, to realise informational economies and to benefit from economies of scale (Kogut, 1983). The first two avantages appear to be particularly salient for explaining possible differences of political influence between a MNE and a purely domestic company.

First of all, multinationalisation contributes to the credibility of the relocation threats of MNE. If a firm disagrees with a government about the proposal of a new regulation, it can threaten the government to relocate its operations to another country. A MNE is likely to be more credible than a domestic firm because its moving costs abroad are smaller (Kogut, 1983; Polk, 2002; Ietto-Gillies, 2002). Developing countries, in their eagerness to attract foreign firms are willing to grant them short-run incentives (Oman, 2000), which reduce the cost of moving to another country. If a MNE already runs a plant in another country, it will be easier to

\footnotetext{
${ }^{17}$ The national preference model assumes that the country is democratic. In an authoritarian country, it is possible that foreign producers will be privileged, because they are less likely to contest the established political regime.

${ }^{18}$ Since a foreign affiliate does not always have a clear nationality, depending on its degree of foreign ownership, government policies models are more likely to apply to majority-owned foreign firms, which involve few domestic interests.

${ }^{19}$ In Dunning's terminology, the $O^{t}$ (the firm-specific transaction advantages) arise from the multinationalisation made possible by the $O^{a}$ (the firm-specific asset advantages).
} 
expand it than build one from scratch, as will be the case for a purely domestic firm. ${ }^{20}$ Finally, MNE possess greater experience in managing institutional idiosyncracies than domestic firms (Henisz, 2003), which should result in their greater capability to relocate their activities to another country, even if the latter is geographically distant and culturally dissimilar (Davidson, 1980). According to Cowling and Tomlinson (2005), MNE make a frequent use of the relocation threat, i.e. a "divide and rule" strategy, to obtain the introduction or maintenance of profitable measures. $^{21}$

Multinationalisation also allows for the acquisition of lobbying experience since entering and operating in different countries certainly encourage MNE to develop this kind of specific advantage (Boddewyn, 1988; Grether et al., 2001). Thus, a MNE should be more accustomed to dealing with public officials than a domestic firm.

These arguments imply that a MNE should exert more political influence on government regulations than a purely domestic firm. However, MNE can either be domestic, ${ }^{22}$ foreign or both. Since domestic MNE theoretically share with foreign MNE a similar level of threat credibility and international experience, a foreign firm may not have more political influence than a domestic MNE. It is unclear what would be the relative degree of political influence of a hybrid MNE, i.e. a foreign MNE which is also a domestic MNE. Its combination of both foreign-imported and domestically-obtained firm-specific and transaction advantages, could give it more relocation options or more lobbying experience and therefore higher political influence, in comparison to domestic or foreign MNE.

\section{Summary of various determinants and empirical evidence}

Table 3 summarises the determinants of a foreign firm's political influence over host country government policies, compared to a domestic firm. The strength of a foreign firm's political influence results in fine from the relative weight of each of these determinants.

Empirical evidence on the capacity of foreign firms to politically influence their business en-

\footnotetext{
${ }^{20}$ Kogut (1983) considers that operating on purpose plants at less than full capacity in other foreign countries is a strategy which provides a MNE with more bargaining power in negotiating with a government.

${ }^{21}$ According to Ietto-Gillies (2002), the "divide and rule" strategy was already at the heart of Hymer's concerns when he was examining, in the seventies, the relations between MNE and host country governments or workers.

${ }^{22}$ South-south FDI flows is a growing phenomenon. Aykut and Ratha (2004) estimate that in 2000, more than one third of the FDI flows reported by developing countries, originate from other developing countries.
} 
vironment is scarce but seems to point out that foreign firms are privileged by the government. Thus, using the WBES data, Nagarajan (2001), Schiffer and Weder (2001), Batra et al. (2002) and Huang (2004) uncover that foreign firms appear to be less constrained by the business environment than domestic firms, even after controlling for firm-specific and country-specific effects. ${ }^{23}$ In other words, these studies put forward that the foreign-privilege hypothesis finds more empirical ground than the national-preference hypothesis; foreign firms benefit from advantages (frequently in terms of regulatory and fiscal concessions) which are denied to their domestic counterparts. However, besides Huang (2004), none of these papers have tried to explain the underpinning of these results. This author argues that foreign firms are only privileged against the politically weak domestic firms, implicitly suggesting that the origin of the advantages enjoyed by certain firms should be tracked back to their political behaviour.

\section{An econometric test of the comparative political in- fluence of foreign and domestic firms}

It is possible that foreign firms are privileged by the government because they are more successful than domestic firms in shaping the business environment in their favour. Indeed, table 4 illustrates that on average, foreign firms [FDI], defined as firms in which a foreign investor owns $10 \%$ or more of the ordinary shares, are more influential than domestic firms $;^{24}$ the measure of political influence is the variable described in section II. However, before asserting with certainty that foreign firms are more influential than domestic firms, firm-specific characteristics and country-specific effects need to be econometrically controlled for.

\section{Model specification}

In terms of firm characteristics, the WBES data provide information on the origin of the firm, its size, its year of establishment, its sector, its export activity, and its operations in other countries.

\footnotetext{
${ }^{23}$ Firms were asked to rate eleven constraints to their business operations and growth: financing, infrastructure, taxes and regulations, policy instability/uncertainty, inflation, exchange rate, functioning of the judiciary, corruption, street crime, organised crime and anti-competitive practices by government or private enterprises. Huang (2004) also uses as dependant variables the answers to the question asking firms to judge how problematic are different regulatory areas for the operation and growth of their business (e.g. business licensing, foreign trade or labour regulations, tax regulations, administration).

${ }^{24} \mathrm{~A}$ comparison of means test indicates that this difference is significant at the $1 \%$ level.
} 


\begin{tabular}{|l|c|}
\hline $\begin{array}{l}\text { Determinants of political influence } \\
\text { firm compared to a domestic firm }\end{array}$ & $\begin{array}{c}\text { Political influence of a foreign } \\
\text { Yes }\end{array}$ \\
\hline $\begin{array}{l}\text { Is the technology of the foreign } \\
\text { firm valuable to the government? }\end{array}$ & + \\
$\begin{array}{l}\text { Does the foreign firm lack } \\
\text { domestic legitimacy and is } \\
\text { economic nationalism favoured } \\
\text { by the government or voters? }\end{array}$ & - \\
$\begin{array}{l}\text { Does the domestic firm operate } \\
\text { in another country? }\end{array}$ & \\
\hline
\end{tabular}

Notes: '十': greater political influence, '=': same political influence, '-': lower political influence

Table 3: Determinants of the relative political influence of a foreign firm

\begin{tabular}{|l|ccccccc|}
\hline \multirow{2}{*}{ Ownership } & \multicolumn{7}{|c|}{ Degree of political influence } \\
& Never & Seldom & Influential & Frequently & Very & Mean & Obs \\
\hline \multirow{2}{*}{ No FDI } & $81 \%$ & $11 \%$ & $4 \%$ & $2 \%$ & $1 \%$ & 1.30 & 3516 \\
FDI & $67 \%$ & $20 \%$ & $8 \%$ & $4 \%$ & $1 \%$ & 1.52 & 569 \\
\hline
\end{tabular}

Notes: $\%$ of sample.

Table 4: Summary statistics for the firm-level measure of political influence, by ownership 
In line with Hellman et al. (2002, 2003), these variables will control for other determinants of a firm's political influence, apart from its foreign ownership.

First, it is likely that depending on their origin, firms do not possess the same ties with the state. Hence, firms have been divided in four categories, based on their reported origin of establishment. Firms can either be: 1) originally private from time of start-up with no stateowned predecessor or a joint-venture between foreign and domestic private partners [PRIV] 2) privatised or a private subsidiary of a formerly state-owned firm [FSO] 3) state-owned [SO] or 4) a co-operative (COOP). State-owned firms or recently privatised firms should enjoy an easier access to the state and should be more experienced in dealing with public officials than private firms (Hellman et al., 2002). Moreover, interests of state-owned firms may matter more to a government than those of other firms since the former may be seen as instruments of government policies. Thus, in agreement with the findings of Hellman et al. (2002) for a sample of firms located exclusively in East Europe and Central Asia, it is expected that privatised or state-owned firms will be more influential than private firms.

Second, the political influence of a firm certainly depends on its size. A government should treat preferentially large firms since the evolution of their economic activities affects a high number of workers and, potentially, voters (Schiffer and Weder, 2001; Hellman et al., 2002). Moreover, large firms may have the possibility to devote more resources to lobbying activities than smaller firms. However, a high size implies a higher exposure to public scrutinity, which may hinder the use of political influence when a publicly sensitive issue is addressed by a new regulation. Expected sign of this variable is therefore uncertain. Firms have been divided in three categories, based on the number of employees: small (50 or fewer employees) [SMALL], medium (between 50 and 500 employees) [MEDIUM] or large (more than 500 employees) [LARGE] firms.

Third, the age of the firm [AGE] is included among the control variables. An experienced firm is probably more acquainted with the machinery of state and has acquired more domestic legitimacy than a newly-established firm (Schiffer and Weder, 2001).

Fourth, the government may be more sensitive to the interests of certain industries, for electoral or economic reasons. Firms can belong either to the agricultural sector [AGRI], manufacturing sector [MANUF], service sector [SERV], or another non-specified sector [ANS].

Fifth, a firms which exports part of its production should possess more political leverage than 
a firm uniquely selling its production in the local market. An export-oriented firm can threaten the government to serve the export market through foreign direct investment, resulting in a loss of capital/ jobs and foreign currency. A government is therefore more likely to be sensitive to the interests of firms which export [EXP].

Finally, to take into account that firms can either be purely domestic, domestic MNE, foreign MNE or hybrid MNE, four dummies are created. A purely domestic firm [DOMESTIC] is a firm in which a foreign investor owns less than $10 \%$ of the ordinary shares and which has no operations in other countries. A domestic MNE [DOMESTIC MNE] is a firm which is not foreign-owned and which has operations in other countries. A foreign MNE [FOREIGN MNE] is a firm in which a foreign investor owns $10 \%$ or more of the ordinary shares and which does not operate in other countries. Finally, a hybrid MNE [HYBRID MNE] is a firm which is foreignowned and which has operations in other countries. Domestic and foreign MNE should benefit from the same advantages given by international operations to foreign MNE. A hybrid MNE may exert more political influence than domestic or foreign MNE thanks to greater lobbying experience or higher level of relocation threat credibility. Note that the foreign firm dummy is equal to the sum of the foreign MNE and hybrid MNE dummies; replacing the FDI variable by these two dummies allows the decomposition of the overall foreign dummy effect.

Table 5 provides a summary of the different variables. Beyond these firm-level determinants, the political influence of firms depends on the characteristics of the country in which they operate, too. It is probable that these characteristics vary across countries and therefore unobserved cross-country heterogeneity needs to be taken into account. Otherwise, estimations are biased since they suffer from an omitted variables problem. Unobserved country-specific factors are captured through country fixed effects $[\mathrm{C}]$.

An ordered probit model is used as the values of the dependent variable only reflect an opinion ranking and not meaningful relative differences; a linear regression would assume that the difference between a ' 2 ' and a ' 1 ' is the same as that between a '4' and a '3' (Greene, 2003, p.736). The ordered probit model avoids this assumption. The original structural model takes the following form for $i$ firms belonging to $c$ countries: ${ }^{25}$

\footnotetext{
${ }^{25}$ The presentation of the model heavily draws on Long and Freese (2003)[chap. 5].
} 


\begin{tabular}{|c|c|c|c|c|}
\hline Variable & Mean & Std. Dev & Min. & Max \\
\hline \multicolumn{5}{|l|}{ Dependent variables } \\
\hline POLITICAL INFLUENCE (INF.) & 1.33 & 0.75 & 1 & 5 \\
\hline POLITICAL INFLUENCE OVER EXECUTIVE** & 1.31 & 0.77 & 1 & 5 \\
\hline POLITICAL INFLUENCE OVER LEGISLATIVE* & 1.29 & 0.74 & 1 & 5 \\
\hline POLITICAL INFLUENCE OVER MINISTRY** & 1.31 & 0.76 & 1 & 5 \\
\hline POLITICAL INFLUENCE OVER REG. AGENCY* & 1.31 & 0.77 & 1 & 5 \\
\hline FINANCING CONSTRAINT** & 2.92 & 1.12 & 1 & 4 \\
\hline TAXES AND REGULATIONS* (TAXREG) & 1.90 & 0.96 & 1 & 4 \\
\hline REGULATIONS* & 2.42 & 0.60 & 1 & 4 \\
\hline \multicolumn{5}{|l|}{ Independent variables } \\
\hline FOREIGN FIRM (FDI) & 0.14 & 0.35 & 0 & 1 \\
\hline PURELY DOMESTIC FIRM & 0.78 & 0.42 & 0 & 1 \\
\hline FOREIGN MNE (F. MNE) & 0.07 & 0.25 & 0 & 1 \\
\hline DOMESTIC MNE & 0.08 & 0.28 & 0 & 1 \\
\hline HYBRID MNE (H. MNE) & 0.07 & 0.26 & 0 & 1 \\
\hline PRIVATE (PRIV) & 0.73 & 0.45 & 0 & 1 \\
\hline PRIVATISED (FSO) & 0.15 & 0.36 & 0 & 1 \\
\hline STATE-OWNED (SO) & 0.01 & 0.10 & 0 & 1 \\
\hline COOPERATIVE (COOP) & 0.06 & 0.23 & 0 & 1 \\
\hline SMALL & 0.39 & 0.49 & 0 & 1 \\
\hline MEDIUM & 0.44 & 0.50 & 0 & 1 \\
\hline LARGE & 0.17 & 0.38 & 0 & 1 \\
\hline AGRICULTURAL SECTOR (AGRI) & 0.06 & 0.24 & 0 & 1 \\
\hline MANUFACTURING SECTOR (MAN) & 0.33 & 0.47 & 0 & 1 \\
\hline SERVICE SECTOR (SERV) & 0.42 & 0.49 & 0 & 1 \\
\hline AGE & 18.44 & 21.14 & 0 & 193 \\
\hline EXPORTING FIRM (EXP) & 0.31 & 0.46 & 0 & 1 \\
\hline Number of observations & \multicolumn{4}{|c|}{4085} \\
\hline
\end{tabular}

Note '*' indicates that the variable is defined and used in section V. Abbreviations are indicated in parentheses.

Table 5: Summary statistics 


$$
\begin{aligned}
& y_{i}^{*}=\beta X_{i}+\epsilon_{i} \\
& y_{i}^{*}=\beta_{1} F D I_{i}+\beta_{2} P R I V_{i}+\beta_{3} F S O_{i}+\beta_{4} M E D I U M_{i}+\beta_{5} L A R G E_{i}+ \\
& \beta_{6} A G R I_{i}+\beta_{7} M A N_{i}+\beta_{8} S E R V_{i}+\beta_{9} A G E_{i}+\beta_{10} E X P_{i}+\sum_{1}^{48} \beta_{11} C_{c}+\epsilon_{i}
\end{aligned}
$$

where $y_{i}^{*}$ is a latent variable, ranging from $-\infty$ to $\infty$, which can be thought of as the propensity of firms to consider themselves influential, and $\epsilon_{i}$ is a random error. The base categories are state-owned firms [SO], small size firms [SMALL] and firms belonging to a non-specified sector [ANS].

The measurement model divides $y^{*}$ into five categories, corresponding to the answers of the firms: (1) never influential (2) seldom influential (3) influential (4) frequently influential (5) very influential:

$$
y_{i}=m \quad \text { if } \quad \tau_{m-1} \leq y_{i}^{*}<\tau_{m}
$$

where $y$ is the observed measure of political influence, which takes a value $m$ between 1 and $5 ; \tau_{1}$ to $\tau_{4}$ are four estimated cut-points and the endpoint categories 1 and 5 correspond to $\tau_{0}=-\infty$ and $\tau_{5}=\infty$. When $y_{i}^{*}$ is higher than a threshold value $\tau$, the observed category changes. The predicted probability of an observed outcome $y$ for a given value of the independent variables is:

$$
\begin{aligned}
& \operatorname{Pr}(y=m \mid X)=\operatorname{Pr}\left(\tau_{m-1} \leq y^{*}<\tau_{m} \mid X\right) \\
& \operatorname{Pr}(y=m \mid X)=F\left(\tau_{m}-\beta X\right)-F\left(\tau_{m-1}-\beta X\right)
\end{aligned}
$$

where $F$ corresponds to the cumulative density function for $\epsilon$ : $F$ is normal with $\operatorname{Var}(\epsilon)=1$.

Studies using an ordinal regression model frequently do not test for the parallel regression assumption (Williams, 2006). The ordered probit model can be written as:

$$
\operatorname{Pr}(y \leq m \mid X)=F\left(\tau_{m}-\beta X\right)
$$


with $m=1$ to 4 . The ordered probit model can be seen as equivalent to 4 binary regressions. A critical assumption is therefore that the parameters $\beta$ are identical across each regression. If this is not the case, an alternative model must be used. A Wald test, devised by Brant (1990), allows the testing of the parallel regression assumption for each variable individually. If a variable violates this assumption, a partial proportional odds model can be used, in which some of the $\beta$ coefficients can be constrained to be the same for all values of $m$, while the $\beta$ coefficients of the offending variables can differ (Williams, 2006). In the following discussion of the estimation results, it will be indicated whether a variable violates the parallel regression assumption and whether partial relaxation of the parallel lines constraint modifies the conclusions derived from an ordered probit model.

\section{Estimation results}

Estimation results are given in table 6. An omitted variable test, known as the linktest, indicates that the model is well specified. ${ }^{26}$ Regression (1) shows that most variables are significant. Size, experience, export activity and state ownership are positive and significant determinants of a firm's political influence. The variable of interest, FDI, is highly significant and indicates that foreign firms have a slight advantage over domestic firms in terms of political influence: with values of other variables held at their mean, there is a $22 \%(16 \%)$ predicted probability that a foreign (domestic) firm exerts some political influence on the government. Thus, governments appear to give more voice to foreign firms, suggesting that the national preference hypothesis should be rejected, in favour of the two other arguments, outlined in section III. Regression (2) investigates whether the foreign privilege effect is persistent across developing regions. For this purpose, an interaction term (FDI * ECA), which takes the value of one if the foreign firm is located in East Europe and Central Asia, is added. Focus on this region is justified by the fact that foreign firms may have more opportunities to influence the government when a new set of political and economic institutions is under development. However, this does not appear to be the case since the interaction term is negative and not significant, implying that the foreign privilege effect is the global norm rather than a regional exception.

\footnotetext{
${ }^{26}$ The idea behind the linktest is that if the model is well-specified no other regressors need to be included. Test of this hypothesis relies on the regression of the dependent variable on its predicted value and its predicted value squared. If the model is well-specified, coefficient of the predicted value should be positive and significant whereas the coefficient of the predicted value squared should not be significant, as is the case for regressions (1) to $(4)$.
} 


\begin{tabular}{|c|c|c|c|c|}
\hline \multirow{2}{*}{ Determinants } & \multicolumn{3}{|c|}{ Political influence } & \multirow{2}{*}{$\begin{array}{l}\text { Financing constraint } \\
(4) \\
\end{array}$} \\
\hline & $(1)$ & $(2)$ & $(3)$ & \\
\hline FDI & $0.226^{a}$ & $0.240^{a}$ & & \\
\hline & $(0.070)$ & $(0.076)$ & & \\
\hline FDI * ECA & & -0.055 & & \\
\hline HYBRID MNE & & $(0.172)$ & $0.387^{a}$ & $-0.462^{a}$ \\
\hline & & & $(0.085)$ & $(0.069)$ \\
\hline DOMESTIC MNE & & & 0.079 & 0.025 \\
\hline & & & $(0.070)$ & $(0.063)$ \\
\hline FOREIGN MNE & & & 0.057 & $-0.221^{a}$ \\
\hline & & & $(0.086)$ & $(0.077)$ \\
\hline PRIV & $-0.347^{a}$ & $-0.346^{a}$ & $-0.347^{a}$ & $-0.264^{a}$ \\
\hline & $(0.093)$ & $(0.092)$ & $(0.093)$ & $(0.088)$ \\
\hline FSO & -0.137 & -0.136 & -0.139 & -0.036 \\
\hline & $(0.118)$ & $(0.118)$ & $(0.119)$ & $(0.105)$ \\
\hline COOP & 0.137 & 0.134 & 0.137 & 0.083 \\
\hline & $(0.152)$ & $(0.152)$ & $(0.152)$ & $(0.164)$ \\
\hline MEDIUM & $0.339^{a}$ & $0.340^{a}$ & $0.338^{a}$ & $-0.166^{a}$ \\
\hline & $(0.077)$ & $(0.076)$ & $(0.077)$ & $(0.060)$ \\
\hline LARGE & $0.554^{a}$ & $0.554^{a}$ & $0.542^{a}$ & $-0.325^{a}$ \\
\hline & $(0.086)$ & $(0.086)$ & $(0.088)$ & $(0.075)$ \\
\hline AGE & $0.006^{a}$ & $0.006^{a}$ & $0.006^{a}$ & $-0.002^{c}$ \\
\hline & $(0.001)$ & $(0.001)$ & $(0.001)$ & $(0.001)$ \\
\hline EXP & $0.113^{b}$ & $0.114^{b}$ & $0.100^{c}$ & .008 \\
\hline & $(0.057)$ & $(0.057)$ & $(0.055)$ & $(0.060)$ \\
\hline Observations & 4085 & 4085 & 4085 & 4055 \\
\hline Pseudo R & 0.11 & 0.11 & 0.11 & 0.06 \\
\hline Prob $>\mathrm{Chi}^{2}$ & 0.00 & 0.00 & 0.00 & 0.00 \\
\hline Log pseudolikelihood & -2634.29 & -2634.22 & -2629.35 & -4948.04 \\
\hline Cut 1 & 1.60 & 1.60 & 1.60 & -1.02 \\
\hline Cut 2 & 2.27 & 2.27 & 2.27 & -.48 \\
\hline Cut 3 & 2.78 & 2.78 & 2.78 & .26 \\
\hline Cut 4 & 3.29 & 3.29 & 3.30 & - \\
\hline
\end{tabular}

Notes: a, b, c denotes respectively significance at the 1, 5 and $10 \%$ level.

Robust-cluster standard errors are in parentheses. Unreported industry and country dummies are included. Sector and country dummies are jointly significant at the $1 \%$ level.

Table 6: The political influence of foreign firms over government regulations 
It has been previously argued that it is not clear whether domestic and foreign MNE should diverge in terms of political influence, since they benefit from the same advantages granted by their international operations. However, hybrid MNE, i.e. a foreign MNE which is also a domestic MNE, may be more influential because of greater lobbying experience or higher relocation threat credibility. In order to disentangle this issue, two dummies, respectively indicating whether the observed firm is a hybrid MNE or a foreign MNE, replace the FDI variable. In addition, a domestic MNE dummy is included and the base category corresponds now to purely domestic firms. Regression (3) shows that only hybrid MNE are more influential than other firms. Compared to a purely domestic firm, the predicted probability of exerting some political influence on the government increases from $16 \%$ to $27 \%$ if a firm is a hybrid MNE. Foreign and domestic MNE appear to be slightly more influential than a purely domestic firm but their coefficients are not significant. ${ }^{27}$ Hence, the potential contribution of foreign MNE to economic growth does not appear to be a source of political influence, since domestic MNE and foreign MNE possess about the same political influence. It follows that hybrid MNE are more influential than all other firms, including domestic and foreign MNE, because they benefit from stronger economies of common governance. For instance, it may be easier for a hybrid MNE to relocate if they are not constrained by the lack of financing, giving more credibility to its threat (Grether et al., 2001). Regression (4) tests such hypothesis, using as dependent variable answers to the following question "Please judge on a four point scale how problematic are the following factors for the operation and growth of your business: financing. (1) No obstacle (2) Minor obstacle (3) Moderate obstacle (4) Major obstacle". Results indicate that, whereas for domestic MNE, the predicted probability that a firm finds that financing is not an obstacle or only a minor one equals $30 \%$, the predicted probabilities for foreign and hybrid MNE are respectively 8 percentage points and 17 percentage points greater. Thus, easier access to foreign and domestic sources of financing is certainly one of the characteristics which differentiate hybrid MNE from domestic MNE and to a certain extent, from foreign MNE.

Robustness checks have been carried out in order to verify the stability of these results. First, exploration of the parallel regression assumption, through the Brant (1990) test, points out that only the exporting dummy violates this condition, at the $5 \%$ level. The use of a partial

\footnotetext{
${ }^{27}$ Interestingly, the coefficient of the FDI dummy is about equal to the average of coefficients of hybrid and foreign dummies. This decomposition indicates which type of foreign firms drive the overall FDI dummy effect.
} 
proportional odds model shows that for high values of political influence, exporters lose their political influence advantage. Coefficients and significance of other variables, including variables of interest, are unaffected. Second, conclusions are qualitatively similar when an alternative measure of political influence is used: "In case of important changes in laws or policies affecting my business operation the government takes into account concerns voiced either by me or by my business association. This is true (1) always, (2) mostly, (3) frequently, (4) sometimes, (5), seldom, (6) never". ${ }^{28}$ Third, it is investigated whether the degree of political influence of foreign firms varies when a distinction is operated between policy-makers (executive and legislative) and policy-enforcers (ministries and regulatory agencies). ${ }^{29}$ On the one hand, in line with the government policy model, elected officials should be more sensitive to the interest of domestic producers. On the other hand, officials who enforce regulations are less politically accountable and are often given some room for the design and interpretation of new rules, within their constitutional competencies. Hence, the latter may be most plausible interlocutors of foreign firms. They will be both more likely to take into account the concerns of foreign investors and at the same time more likely to be the targets of foreign firms' lobbying. Table 7 confirms this line of reasoning since the probabilities that hybrid MNE enjoy some political influence over policymakers or over policy-enforcers equal respectively $20 \%$ and $25 \%$, a 5 percentage points difference. Interestingly, the most accountable branch of the government, the executive, gives more weight to domestic MNE than to foreign MNE. Thus, although host country governments are not globally hostile to foreign firms, politicians tend to grant slightly more political importance to domestic firms than other officials.

To sum up, it has been shown that governments in developing countries do not discriminate against foreign firms, suggesting that the bargaining power of foreign firms is generally high enough to outweigh any political lability of foreignness. However, distinguishing between the different types of MNE reveal that only hybrid MNE are more influential than purely domestic firms. Their superior political influence is likely to result from the combination of both foreignimported and domestically-obtained firm-specific and transaction advantages, i.e. from their extensive multinationality, rather from their expected contribution to economic growth.

\footnotetext{
${ }^{28}$ Results are available upon request to the authors.

${ }^{29}$ Each measure of political influence over a distinct government branch has been submitted to the same correction as the overall measure of political influence: whichever the value of the influence variable, a firm is considered to exert some political influence over a government branch only if it reports never or seldom paying bribes.
} 


\begin{tabular}{|c|c|c|c|c|}
\hline \multirow{3}{*}{ Determinants } & \multicolumn{4}{|c|}{ Political influence over nolicu } \\
\hline & \multicolumn{2}{|c|}{ Executive } & \multicolumn{2}{|c|}{ Legislative } \\
\hline & (5) & $(6)$ & $(7)$ & (8) \\
\hline FDI & \multicolumn{2}{|l|}{$\begin{array}{c}0.145^{c} \\
(0.078)\end{array}$} & \multicolumn{2}{|l|}{$\begin{array}{c}0.173^{b} \\
(0.079)\end{array}$} \\
\hline HYBRID MNE & \multicolumn{2}{|r|}{$0.268^{a}$} & \multicolumn{2}{|r|}{$\begin{array}{c}0.328^{a} \\
(0.099)\end{array}$} \\
\hline \multirow[t]{2}{*}{ DOMESTIC MNE } & \multicolumn{2}{|r|}{$0.136^{c}$} & \multicolumn{2}{|r|}{0.037} \\
\hline & & $(0.072)$ & & $(0.082)$ \\
\hline \multirow[t]{2}{*}{ FOREIGN MNE } & & 0.053 & & -0.013 \\
\hline & & $(0.095)$ & & $(0.093)$ \\
\hline \multirow{3}{*}{ Determinants } & \multicolumn{4}{|c|}{ Political influence over policy-enforcers } \\
\hline & \multicolumn{2}{|c|}{ Ministries } & \multicolumn{2}{|c|}{ Regulatory agencies } \\
\hline & (9) & $(10)$ & (11) & $(12)$ \\
\hline FDI & $0.232^{a}$ & & $0.241^{a}$ & \\
\hline & $(0.066)$ & & $(0.071)$ & \\
\hline HYBRID MNE & & $0.379^{a}$ & & $0.381^{a}$ \\
\hline & & $(0.085)$ & & $(0.086)$ \\
\hline DOMESTIC MNE & & 0.061 & & 0.089 \\
\hline & & $(0.078)$ & & $(0.072)$ \\
\hline FOREIGN MNE & & 0.073 & & 0.103 \\
\hline & & $(0.086)$ & & $(0.085)$ \\
\hline
\end{tabular}

Notes: a, b, c denotes respectively significance at the 1,5 and $10 \%$ level. Ordered probit model. Robust-cluster standard errors are in parentheses. Unreported firm-specific and country-specific variables included.

Table 7: The political influence of foreign firms on each government branch 


\section{The preferential treatment of influential and foreign firms by the government}

Firms are likely to use their political influence to benefit from fiscal and regulatory advantages denied to non-influential firms. Furthermore, foreign MNE may have chosen to invest in a particular country because they have been promised regulatory concessions and lower taxes by the government. Thus, it is possible that influential and foreign firms enjoy a better business environment than other firms.

Both hypotheses are tested in table 8, in which the dependent variable (TAXREG) is now the answer to the following question: "Please judge on a four point scale how problematic are the following factors for the operation and growth of your business: Taxes and regulations. (1) No obstacle (2) Minor obstacle (3) Moderate obstacle (4) Major obstacle". This business obstacle is general enough to encompass most of the business constraints faced by firms and it corresponds to an aspect of the business environment which is unambiguously under the control of the government (Huang, 2004). For ease of reading, the scale of the dependent variable has been reversed such as "1" corresponds to the "major obstacle" category and "4" to the "no obstacle" category.

Regressions (13) and (14) confirm that foreign and influential firms feel less constrained by their business environment than other firms. ${ }^{30}$ The regulatory advantages of foreign firms do not seem to primarily derive from their political influence since introducing the political influence variable in regression (14) does not substantially affect neither the significance nor the magnitude of the FDI coefficient. The predicted probabilities that a firm considers that taxes and regulations are not an obstacle or only a minor one equal $27 \%$ (21\%) for a foreign (domestic) firm and 34\% (20\%) for a fully influential (non-influential) firm. Compared to a non-influential domestic firm, this probability rises from $20 \%$ to $40 \%$ in the case of a fullyinfluential foreign firm. Concerning the control variables, few are significant: only cooperative and exporting firms appear to be privileged. The Brant (1990) test underscores that only the age of the firm violates the parallel line regressions. The use of a partial proportional odds model shows that the relationship between the perception of taxes and regulations as a burden

\footnotetext{
${ }^{30}$ The linktest indicates that the model is well specified.
} 


\begin{tabular}{|c|c|c|c|c|c|c|c|}
\hline Determinants & \multicolumn{4}{|c|}{ Taxes and regulations } & & & $\begin{array}{c}\text { Regulations } \\
\text { (19) }\end{array}$ \\
\hline FDI & $\begin{array}{c}0.196^{a} \\
(0.052)\end{array}$ & $\begin{array}{c}0.185^{a} \\
(0.051)\end{array}$ & $\begin{array}{c}0.197^{a} \\
(0.052)\end{array}$ & $\begin{array}{l}0.200^{a} \\
(0.051)\end{array}$ & & & \\
\hline HYBRID MNE & & & & & $\begin{array}{c}0.276^{a} \\
(0.080)\end{array}$ & $\begin{array}{c}0.248^{a} \\
(0.085)\end{array}$ & $\begin{array}{c}.168^{b} \\
(0.086)\end{array}$ \\
\hline H.MNE $*$ AGE & & & & & & $\begin{array}{c}0.001 \\
(0.002)\end{array}$ & \\
\hline DOMESTIC MNE & & & & & $\begin{array}{c}0.031 \\
(0.072)\end{array}$ & $\begin{array}{c}0.029 \\
(0.072)\end{array}$ & $\begin{array}{l}-0.078 \\
(0.058)\end{array}$ \\
\hline FOREIGN MNE & & & & & $\begin{array}{c}0.126^{b} \\
((0.056)\end{array}$ & $\begin{array}{c}0.183^{b} \\
(0.089)\end{array}$ & $\begin{array}{c}0.051 \\
(0.067)\end{array}$ \\
\hline F. $\mathrm{MNE}^{*} \mathrm{AGE}$ & & & & & & $\begin{array}{l}-0.003 \\
(0.003)\end{array}$ & \\
\hline INF. & & $\begin{array}{c}0.103^{a} \\
(0.030)\end{array}$ & $\begin{array}{c}0.096^{a} \\
(0.029)\end{array}$ & $\begin{array}{c}0.060 \\
(0.037)\end{array}$ & $\begin{array}{c}0.094^{a} \\
(0.029)\end{array}$ & $\begin{array}{c}0.094^{a} \\
(0.029)\end{array}$ & $\begin{array}{c}0.067^{a} \\
(0.026)\end{array}$ \\
\hline INF. * ECA & & & & $\begin{array}{c}0.106^{b} \\
(0.052)\end{array}$ & & & \\
\hline PRIV & 0.080 & 0.097 & 0.108 & 0.109 & 0.109 & 0.106 & 0.102 \\
\hline & $(0.075)$ & $(0.073)$ & $(0.072)$ & $(0.071)$ & $(0.072)$ & $(0.073)$ & $(0.073)$ \\
\hline FSO & -0.076 & -0.067 & -0.063 & -0.060 & -0.064 & -0.064 & -0.011 \\
\hline & $(0.125)$ & $(0.124)$ & $(0.124)$ & $(0.123)$ & $(0.124)$ & $(0.124)$ & $(0.112)$ \\
\hline $\mathrm{COOP}$ & $0.315^{b}$ & $0.312^{b}$ & $0.304^{b}$ & $0.289^{b}$ & $0.304^{b}$ & $0.303^{b}$ & $0.186^{c}$ \\
\hline & $(0.135)$ & $(0.135)$ & $(0.133)$ & $(0.134)$ & $(0.134)$ & $(0.135)$ & $(0.110)$ \\
\hline MEDIUM & 0.020 & 0.008 & 0.015 & 0.015 & 0.015 & 0.014 & -0.033 \\
\hline & $(0.040)$ & $(0.042)$ & $(0.041)$ & $(0.040)$ & $(0.041)$ & $(0.041)$ & $(0.039)$ \\
\hline LARGE & $0.110^{c}$ & 0.082 & 0.076 & 0.081 & 0.071 & 0.071 & 0.001 \\
\hline & $(0.060)$ & $(0.064)$ & $(0.063)$ & $(0.063)$ & $(0.064)$ & $(0.064)$ & $(0.053)$ \\
\hline AGE & 0.000 & 0.000 & 0.000 & 0.000 & 0.000 & 0.000 & 0.000 \\
\hline & $(0.001)$ & $(0.001)$ & $(0.001)$ & $(0.001)$ & $(0.001)$ & $(0.001)$ & $(0.001)$ \\
\hline EXP & $0.086^{c}$ & $0.083^{c}$ & 0.078 & 0.074 & 0.072 & 0.072 & 0.047 \\
\hline & $(0.050)$ & $(0.050)$ & $(0.049)$ & $(0.049)$ & $(0.049)$ & $(0.049)$ & $(0.050)$ \\
\hline KVETCH & & & $-0.103^{a}$ & $-0.103^{a}$ & $-0.103^{a}$ & $-0.104^{a}$ & $-0.058^{a}$ \\
\hline & & & $(0.019)$ & $(0.019)$ & $(0.019)$ & $(0.019)$ & $(0.019)$ \\
\hline Observations & 4085 & 4085 & 4085 & 4085 & 4085 & 4085 & 4031 \\
\hline Pseudo $\mathrm{R}^{2}$ & 0.09 & 0.09 & 0.10 & 0.10 & 0.10 & 0.10 & 0.05 \\
\hline Prob $>\mathrm{Chi}^{2}$ & 0.00 & 0.00 & 0.00 & 0.00 & 0200 & 0.00 & 00 \\
\hline Log Pseudolikelihood & -4574.85 & -4566.30 & -4543.78 & -4541.60 & -4542.43 & -4541.84 & -3394.11 \\
\hline Cut1 & 0.39 & 0.50 & 0.12 & 0.21 & 0.12 & 0.12 & -1.74 \\
\hline Cut2 & 1.37 & 1.48 & 1.11 & 1.20 & 1.11 & 1.11 & 0.67 \\
\hline Cut3 & 2.15 & 2.27 & 1.91 & 2.00 & 1.91 & 1.90 & 2.32 \\
\hline
\end{tabular}

Notes: a, b, c denotes respectively significance at the 1,5 and $10 \%$ level. Robust-cluster standard errors are in parentheses. Unreported industry and country dummies are included. Sector and country dummies are jointly significant at the $1 \%$ level.

Table 8: Fiscal and regulatory advantages granted to influential and foreign firms 
and the year of establishment of a firm exhibits an inversed U-shape. However, the coefficient of AGE is always found to be non-significant, as in the parallel lines model.

These last two regressions may be suffering from a potential perception respondent bias if firms have the tendency to view all questions with the same subjective lens, leading them to give answers which are not justified from an objective standpoint (Kaufmann and Wei, 2000; Batra et al., 2002). In presence of such phenomenon, known as the "kvetch factor," coefficient estimates may be biased by measurement errors and the relationship found between the degree of political influence and the level of taxes and regulations enjoyed by a firm could even be spurious, if it results from their simultaneous correlation with an unobserved factor, such as a general tendency to complain (kvetch in Yiddish). In line with Kaufmann and Wei (2000) and Batra et al. (2002), this potential misspecification issue is addressed through the inclusion of an additional variable, which corresponds to the answers to the following question "Please rate the overall quality and efficiency of services delivered by the following public agencies or services: The Water/Sewerage Service/Agency. (1) Very good (2) Good (3) Slightly Good (4) Slightly Bad (5) Bad (6) Very Bad". Provision of this public good by the government is likely to be identical for all firms and therefore firm-specific deviation from the country mean can be interpreted as an individual measure of perception bias. Interestingly, a comparison of means test of residuals values indicates that domestic and foreign firms tend to share an identical perception bias, implying that subjectivity of respondents is not a function of their nationality. Inclusion of this kvetch measure in regression $(15)^{31}$ reveals the existence of a weak but significant perception bias, which only slightly decreases the coefficient of political influence, relative to regression (14).

The impact of political influence may also diverge across regions. As argued by Hellman et al. (2003), political institutions in East Europe and Central Asia could be particularly vulnerable to corporate meddling. Indeed, regression (16) point outs that political influence of firms is much higher in East Europe and Central Asia than in other developing regions where political influence does not seem to generate any significant fiscal or regulatory benefits. However, if the impact of the political influence over each government branch is examined separately, as in table 9, it appears that firms which are successful at influencing regulatory agencies, i.e. hybrid

\footnotetext{
${ }^{31}$ The kvetch variable does not need to be transformed before including it in regression (15) as country-specific fixed effects are among independent variables.
} 
MNE, will be privileged worldwide: regulatory agencies are likely to be much less accountable to civil society and may enjoy greater discretion power than other government branches, especially concerning the granting of fiscal and financial incentives to investors.

So far, it has been assumed in this section that it is the political influence of firms which allows them to benefit from regulatory advantages denied to non-influential firms. Conversely, it is possible that firms which face lower taxes and regulations may be more influential than other firms. They may, for instance, be able to earmark more resources for political lobbying. The issue of possible reverse causality needs therefore to be addressed. Since it is easier to test and correct for potential endogeneity bias in probit models, two dummies are created, which respectively take the value of one if the firm is at least seldom influential and if taxes or if regulations are not a major obstacle for the firm. Unreported regressions using these two new dependent variables yield results which are comparable to regressions (1) and (15): the probability that a foreign (domestic) firm is influential equals $23 \%$ (16\%) and the probability that a foreign (domestic) firm faces a low regulatory burden equals $27 \%(21 \%) .{ }^{32}$ The perception of inflation as a business constraint is used for instrumenting TAXREG; both assessments of the economic environment in which firms operate are significantly and positively correlated -the Spearman's rank correlation coefficient is 0.32 , significant at the $1 \%$ level, and firms should not be able to influence to their advantage this dimension of the business climate. To test for the exogeneity of TAXREG, the Smith and Blundell (1986) test is used. Similarly to a Davidson and Mackinnon (1993) auxiliary regression test, it consists in regressing the suspected endogenous variable on a set of instruments and to include the residuals from this first-stage regression in the second-stage model. If the variable is exogenous, the residuals should have no explanatory power. The Smith and Blundell (1986) test, yields a Chi-squared(1) test equals to 1.04 with a P-value equals to .31, indicating that the null hypothesis that TAXREG is exogenous, cannot be rejected. ${ }^{33}$ Hence, taxes and regulations to which firms are subject are not an indirect source of political influence.

Turning to the distinctive regulatory and fiscal regimes enjoyed by the three kinds of MNE,

\footnotetext{
${ }^{32}$ Estimations are available upon request to the authors.

${ }^{33}$ On the basis of a two-stages least squares estimation, diagnostic tests have been run, showing that the instrument is valid: the first-stage F-statistic (149) indicates that the instrument is relevant and statistically significant while an Anderson canonical correlations test of instrument relevance validates that the model is identified.
} 


\begin{tabular}{|c|c|c|c|c|}
\hline Determinants/Political influence over & $(20)$ & uxes and & regulatio & s \\
\hline $\begin{array}{c}\text { Executive } \\
\text { Executive }{ }^{*} \mathrm{ECA} \\
\text { Legislative } \\
\text { Legislative }^{*} \mathrm{ECA}\end{array}$ & $\begin{array}{l}0.089^{a} \\
(0.026)\end{array}$ & $\begin{array}{c}0.051 \\
(0.035) \\
0.110^{b} \\
(0.046)\end{array}$ & $\begin{array}{c}0.067^{b} \\
(0.028)\end{array}$ & $\begin{array}{c}0.047 \\
(0.034) \\
0.057 \\
(0.056)\end{array}$ \\
\hline Determinants/Political influence over & $(24)$ & $\begin{array}{l}\text { uxes and } \\
(25) \\
\end{array}$ & $\begin{array}{c}\text { regulatio } \\
(26)\end{array}$ & (27) \\
\hline $\begin{array}{c}\text { Ministry } \\
\text { Ministry * ECA } \\
\text { Regulatory agency } \\
\text { Regulatory agency * ECA }\end{array}$ & $\begin{array}{l}0.094^{a} \\
(0.027)\end{array}$ & $\begin{array}{c}0.056 \\
(0.036) \\
0.099^{b} \\
(0.050)\end{array}$ & $\begin{array}{c}0.107^{a} \\
(0.026)\end{array}$ & $\begin{array}{c}0.072^{c} \\
(0.039) \\
0.101^{b} \\
(0.052)\end{array}$ \\
\hline Observations & 4085 & 4085 & 4085 & 4085 \\
\hline
\end{tabular}

Notes: a, b, c denotes respectively significance at the 1,5 and $10 \%$ level. Robust standard errors are in parentheses.Unreported firm-specific and country-specific variables included.

Table 9: Political influence over government branches and regulatory advantages 
it appears, in regression (17), that foreign and hybrid MNE are privileged by the government while domestic MNE are not better off than purely domestic firms. Compared to a purely domestic firm, the probability that a firm considers that taxes and regulations are not an obstacle or only a minor one increases from $21 \%$ to $25 \%$ (29\%) for a foreign (hybrid) MNE. The opposite signs for domestic and foreign/hybrid MNE dummies suggest that the preferential treatment of the latter does not result from their multinationality; including in regression (15) a dummy which takes the value of one if the firm has operations in other countries supports this hypothesis since its coefficient is small and insignificant. Hence it is likely that the exclusive business conditions enjoyed by foreign firms arise from their ability to negotiate favourable entry terms with the government, in exchange for their expected contribution to host country economic growth. Hybrid MNE may be the most privileged firm category because they are seen by the government as the most dynamic engine of growth: they can contribute to the long-term viability and expansion of the most profitable domestic firms ${ }^{34}$ or their capability to create a domestic MNE may underline the sophistication of their technology. ${ }^{35}$

New frameworks of MNE-host Government Relations, such as Dunning (1998) or Luo (2001) contradict the idea of the "obsolescing bargain" put forward by Vernon (1971). They argue that it is in the interest of governments to entertain long-term cooperative relations with MNE. Such hypothesis is tested in regression (18), through the interaction of foreign and hybrid MNE dummies with the firm age. Size and significance of the interaction terms coefficients suggest that foreign firms do not lose any fiscal or regulatory advantages, in the years subsequent to their entry. This is in line with the temporal shift of MNE-government relations from conflictual towards cooperative (Luo, 2001) and with Safarian (1999)'s review of FDI policies, who concludes that "The key to the new approach to TNCs is that policy on FDI and policy on endogenous growth have converged. TNCs are regarded as central to the creation and diffusion of knowledge, within and between firms, and in cooperation with Governments" (p.108).

The granting of fiscal and financial incentives to foreign investors for the purpose of attract-

\footnotetext{
${ }^{34}$ Studies have shown that performance gaps between foreign and domestic firms are mainly explained by multinationality and not foreign ownership per se (Bellak, 2004).

${ }^{35}$ It could be argued that MNE report that they feel less constrained by taxes than other firms because they can engage into transfer pricing practices, i.e. through overpricing of imports and/or under-pricing of exports between affiliates in different countries, they can transfer profits from high taxes countries to low taxes locations. However, since the three kinds of MNE have at their disposition this tax avoidance instrument, it cannot explain the differences in the coefficients of MNE.
} 
ing them is well-advertised in the literature (Oman, 2000; Charlton, 2003). However, easing the regulatory burden is another way of improving the host country competitiveness. ${ }^{36}$ In order to test whether foreign firms enjoy regulatory concessions, in addition to any fiscal advantage, a new dependent variable is constructed: it is the residual of TAXREG on the answers to the following question "Please judge on a four point scale how problematic are these different regulatory areas for the operation and growth of your business: high taxes (1) No obstacle 2) Minor obstacle 3) Moderate obstacle 4) Major obstacle". The residual has been rescaled and values have been rounded, so, like TAXREG, a (1) means that regulations are a major constraint and (4) no constraint. Regression (19) indicates that only hybrid MNE are likely to enjoy regulatory concessions. For already stated reasons, their bargaining power may be high enough to bend to their advantage the regulatory framework, which may be necessary to preserve their ability to operate on a worldwide scale. Nevertheless, it can be generalised that advantages granted to foreign investors mainly take the form of fiscal incentives.

These results imply that foreign firms enjoy a better business climate than other firms because they have the capability of shaping it at two stages. First, thanks to their expected potential contribution to growth, hybrid and foreign MNE possess enough bargaining power to negotiate their entry conditions with a host country, in terms of regulatory concessions and lower taxes. Second, hybrid MNE derive from their extensive international operations enough political power to influence any new government regulation which may affect their business operations. Hence, the advantages enjoyed by foreign firms over domestic firms are a consequence of two effects: the outcome of their bargaining with the government over their entry conditions, and their subsequent political activism in the host country. This last effect is much stronger in East Europe and Central Asia, where institutions are relatively malleable and civil society weak. Using the estimates of regression (15), one-third of the probability advantage of a fully influential foreign firm over a non influential domestic firm, in terms of facing a low regulatory burden, is explained by nationality and the remaining two-thirds by their diverging political influence. Thus, (foreign) firms which successfully influence the host country government are likely to enjoy a significant competitiveness advantage over their competitors.

\footnotetext{
${ }^{36}$ The World Bank (2004) has shown that it is the poorest countries which regulate the most.
} 


\section{Conclusion}

On the basis of a conceptual framework, this paper has empirically investigated whether foreign and domestic firms possess diverging levels of political influence and whether political influence leads to a better business climate than the one to which non-influential firms are subject. It is globally found that foreign and domestic firms share the same degree of political influence and that political influence provides fiscal and regulatory advantages, especially in countries of East Europe and Central Asia. In addition, it is shown that foreign firms enjoy worldwide a better business environment than all other firms. These exclusive conditions, in terms of regulatory concessions and lower taxes, may be the result of the foreign firm's bargain with the government over favourable entry conditions, in exchange for its expected contribution to host country economic growth. This preferential treatment does not appear to obsolesce over time. Thus, influential and foreign firms are likely to enjoy non-exclusive competitiveness advantages over their competitors.

This paper has demonstrated that the endogenous policy literature has been right to assume that domestic and foreign firms share generally the same degree of political influence, though in the case of hybrid MNE, more voice appears to be given by the government to the latter. This equality of political influence increases the likelihood that foreign firms will be able to shape government policies in a form that suits their private interests. Such strategic political behaviour is not without consequences for the rest of the economy. Successful foreign lobbying for greater market access may be welfare-enhancing, whereas the foreign use of political influence for the obtention or preservation of monopoly privileges is welfare-depressing. Hellman et al. (2002) have shown that foreign investors from OECD countries do not "import" better standards of corporate conduct and governance; they are more likely than domestic firms to engage in corrupt forms of influence in countries where bribing public officials is common and their behaviour does not appear to be affected by home country regulations to prevent bribery. Thus, it is unclear whether the political influence of foreign firms generates positive or negative externalities on the rest of the economy and although FDI is commonly attracted by well-governed countries,

foreign firms do not necessarily contribute to the improvement of the host country business climate. 


\section{References}

Aykut, D. and Ratha, D. (2004), "South-South FDI Flows: How Big Are They ?," Transnational Corporations, vol. 13 no 1: pp. 149-176.

Batra, G., Kaufmann, D. and Stone, A. H. W. (2002), "Voices of the Firms 2000: Investment Climate and Governance Findings of the World Business Environment Survey (WBES)," World Bank Institute Working Paper.

Bellak, C. (2004), "How Domestic and Foreign Firms Differ and Why Does It Matter?," Journal of Economic Surveys, vol. 18 n 4: pp. 483-514.

Bhagwati, J., Dinopoulos, E. and Wong, K.-Y. (1992), "Quid Pro Quo Foreign Investment," American Economic Review, vol. 82 no 2: pp. 186-190.

Bhagwati, J. N. (1987), "Quid Pro Quo DFI and VIEs: A Political-Economy-Theoretic Analysis," International Economic Journal, vol. 1 no 1: pp. 1-14.

Blomström, M. and Kokko, A. (1998), "Multinational Corporations and Spillovers," Journal of Economic Surveys, vol. 12 no 2: pp. 1-25.

Blonigen, B. A. and Figlio, D. N. (1998), "Voting for Protection: Does Direct Foreign Investment Influence Legislator Behavior?," The American Economic Review, vol. 88 n 4 : pp. 1002-1014.

Boddewyn, J. J. (1988), "Political Aspects of MNE Theory," Journal of International Business Studies, vol. 19 n 3: pp. 341-363.

Brant, R. (1990), "Assessing Proportionality in the Proportional Odds Model for Ordinal Logistic Regression," Biometrics, vol. 46 n 4: pp. 1171-1178.

Carr, D. L., Markusen, J. R. and Maskus, K. E. (2001), "Estimating the KnowledgeCapital Model of the Multinational Enterprise," American Economic Review, vol. $91 \mathrm{n}^{\circ} 3$ : pp. 693-708.

Caves, R. E. (1996), Multinational Enterprises and Economic Analysis, Cambridge: Cambridge University Press. 
Charlton, A. (2003), "Incentive Bidding for Mobile Investment: Economic Consequences and Potential Responses," OECD Working Paper, n 203.

Cole, M. A., Elliott, R. J. and Fredriksson, P. G. (2006), "Endogenous Pollution Havens: Does FDI Influence Environmental Regulations?," The Scandinavian Journal of Economics, vol. 108: pp. 157-178.

Cowling, K. and Tomlinson, P. R. (2005), "Globalisation and Corporate Power," Contributions to Political Economy, vol. 24 n 1 : pp. 33-54.

Davidson, R. and Mackinnon, J. G. (1993), Estimation and Inference in Econometrics, New York: Oxford University Press.

Davidson, W. H. (1980), "The Location of Foreign Direct Investment Activity: Country Characteristics and Experience Effects," Journal of International Business Studies, vol. 11 $\mathrm{n}^{\mathrm{o}} 2$ : pp. 9-22.

Dunning, J. H. (1993), Multinational Enterprises and the Global Economy, Wokingham, England and Reading, Mass.: Addison Wesley.

Dunning, J. H. (1998), "An Overview of Relations with National Governments," New Political Economy, vol. 3 no 2: pp. 280-284.

Dunning, J. H. (2001), "The Eclectic (OLI) Paradigm of International Production: Past, Present and Future," International Journal of the Economics of Business, vol. 8 n 2: pp. $173-190$.

Ellingsen, T. and Wärneryd, K. (1999), "Foreign Direct Investment and the Political Economy of Protection," International Economic Review, vol. 40 n 2: pp. 357-379.

Fagre, N. and Wells, L. T. J. (1982), "Bargaining Power of Multinationals and Host Governments," Journal of International Business Studies, vol. 13 n 2: pp. 9-23.

Gawande, K., Krishna, P. and Robbins, M. J. (2004), "Foreign Lobbies and US Trade Policy," NBER Working Paper, no 10205.

Globerman, S. and Shapiro, D. (2003), "Governance Infrastructure and U.S. Foreign Direct Investment," Journal of International Business Studies, vol. 34 n 1 : pp. 19-39. 
Görg, H. and Greenaway, D. (2002), "Much Ado About Nothing? Do Domestic Firms Really Benefit from Foreign Investment?," CEPR Discussion Paper, n3485.

Greene, W. (2003), Econometric Analysis, New York: Prentice Hall.

Grether, J.-M., De Melo, J. and Olarreaga, M. (2001), "Who Determines Mexican Trade Policy?," Journal of Development Economics, vol. 64 n 2: pp. 343-370.

Grossman, G. M. and Helpman, E. (1994), "Protection for Sale," The American Economic Review, vol. $84 \mathrm{n}^{\circ}$ 4: pp. 833-850.

Grossman, G. M. and Helpman, E. (1996), "Foreign Investment with endogenous protection," in Feenstra, R., Grossman, G. and Irwin, D. (editors), The Political Economy of Trade Policy: Papers in Honor of Jagdish Bhagwati, Cambridge: MIT Press.

Hellman, J., Jones, G. and Kaufmann, D. (2002), "Far From Home: Do Foreign Investors Import Higher Standards of Governance in Transition Economies?," World Bank Institute Working Paper.

Hellman, J., Jones, G. and Kaufmann, D. (2003), "Seize the State, Seize the Day: State Capture and Influence in Transition Countries," Journal of Comparative Economics, vol. 31: pp. $751-773$.

Henisz, W. J. (2003), "The Power of the Buckley and Casson Thesis: the Ability to Manage Institutional Idiosyncracies," Journal of International Business Studies, vol. 34 n 2: pp. $173-184$.

Hillman, A. J. and Hitt, M. A. (1999), "Corporate Political Strategy Formulation: A Model of Approach, Participation, and Strategy Decision," The Academy of Management Review, vol. $24 \mathrm{n}^{\circ}$ 4: pp. $825-842$.

Hillman, A. L. and Ursprung, H. W. (1988), "Domestic Politics, Foreign Interests, and International Trade Policy," The American Economic Review, vol. 78 no 4: pp. 729-745.

Hillman, A. L. and Ursprung, H. W. (1993), "Multinational Firms, Political Competition, and International Trade Policy," International Economic Review, vol. 34 no 2: pp. 347-63. 
Huang, Y. (2004), “Are Foreign Firms Privileged by Their Host Governments? Evidence From the 2000 World Business Environment Survey," University of Pennsylvania, Wharton School Working Paper.

Hymer, S. H. (1960), The International Operations of National Firms: A Study of Direct Investment, PhD Thesis, MIT.

IEtTo-Gillies, G. (2002), "Hymer, the Nation-State and the Determinants of Multinational Corporations'Activities," Contributions to Political Economy, vol. 21 n 1 : pp. 43-54.

Kaufmann, D. (2004), "Corruption, Governance and Security: Challenges for the Rich Countries and the World," in López-Claros, A., Porter, M., Sala-I-Martin, X. and Schwab, K. (editors), Global Competitiveness Report 2004/2005, Palgrave Macmillan.

Kaufmann, D. and Wei, S.-J. (2000), "Does 'Grease Money' Speed Up the Wheels of Commerce?," IMF Working Paper, n00/64.

Kaufmann, D., KraAy, A. and Mastruzzi, M. (2004), "Governance Matters III: Governance Indicators for 1996-2002," World Bank Working Paper, n3106.

Kobrin, S. J. (2005), "The Determinants of Liberalization of FDI Policy in Developing Countries: A Cross-sectional Analysis, 1992-2001," Transnational Corporations, vol. 14 no 1: pp. $67-98$.

Kogut, B. (1983), "Foreign Direct Investment as a Sequential Process," in Kindleberger, C. P. and Audretsch, D. B. (editors), The Multinational Corporation in the 1980s, Cambridge, Massachusetts: The MIT Press.

Konishi, H., Saggi, K. and Weber, S. (1999), "Endogenous trade policy under foreign direct investment," Journal of International Economics, vol. 49: pp. 289-308.

Kostova, T. and Zaheer, S. (1999), "Organizational Legitimacy Under Conditions of Complexity: The Case of the Multinational Enterprise," Academy of Management Review, vol. 34 n 1 : pp. 64-81.

Lecraw, D. J. (1984), "Bargaining Power, Ownership, and Profitability of Transnational Corporations in Developing Countries," Journal of International Business Studies, vol. 15 n 1 : pp. 27-43. 
Lipsey, R. E. (2002), "Home and Host Country Effects of FDI," NBER Working Paper, n9293.

Long, S. J. and Freese, J. (2003), Regression Models for Categorical Dependent Variables Using Stata, College Station: Stata Press.

LuO, Y. (2001), "Toward a Cooperative View of MNC-Host Government Relations: Building Blocks and Performance Implications," Journal of International Business Studies, vol. 32 n 3: pp. 401-419.

Mitchell, N. J. (1995), "The Global Polity: Foreign Firms' Political Activity in the United States," Polity, vol. 27 no 3: pp. 447-463.

Moran, T. H. (1998), Foreign Direct Investment and Development: The New Policy Agenda for Developing Countries and Economies in Transition, Washington: Institute for International Economics.

Nagarajan, N. (2001), "Perceptions of the Investment Climate: Foreign vs. Domestic Investors.," FIAS Working Paper.

Olarreaga, M. (1999), "Endogenous Tariffs in the Presence of Foreign Capital," Journal of Economic Integration, vol. $14 \mathrm{n}^{\mathrm{o}}$ 4: pp. 606-624.

Oman, C. (2000), Policy Competition for Foreign Direct Investment: A study of Competition Among Governments to Attract FDI, Paris: OECD.

Polk, A. (2002), "Lobbying Activities of Multinational Firms," University of Zürich Working Paper, n0205.

Safarian, E. A. (1999), "Host Country Policies Towards Inward Foreign Direct Investment in the 1950s and 1990s," Transnational Corporations, vol. 8 n 2: pp. 103-112.

SAGGI, K. (2000), “Trade, Foreign Direct Investment, and International Technology Transfer: A Survey," World Bank Working Paper, n2349.

Schiffer, M. and Weder, B. (2001), "Firm Size and Business Environment: Worldwide survey Results," IFC Discussion Paper, n43.

Smith, R. J. and Blundell, R. W. (1986), "An exogeneity test for a simultaneous equation Tobit model with an application to labor supply," Econometrica, vol. 54 n ${ }^{\circ}$ : pp. 679-686. 
UNCTAD (2003), Foreign Direct Investment and the Performance Requirements: New Evidence From Selected Countries, New York and Geneva: United Nations.

Vachani, S. (1995), "Enhancing the Obsolescing Bargain Theory: A Longitudinal Study of Foreign Ownership of U.S. and European Multinationals," Journal of International Business Studies, vol. $26 \mathrm{n}^{\circ}$ 1: pp. 159-180.

Vernon, R. (1971), Sovereignty at bay, New York: Basic Books.

Williams, R. (2006), "Generalized Ordered Logit/ Partial Proportional Odds Models for Ordinal Dependent Variables," The Stata Journal, vol. 6 n 1: pp. 58-82.

World BANK (2004), Doing Business in 2004: Understanding Regulation, Oxford University Press.

ZAheER, S. (1995), "Overcoming the Liability of Foreignness," Academy of Management Jour-

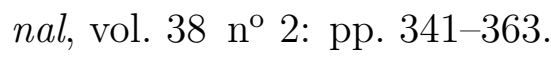

